\title{
Estética literaria de las dictaduras latinoamericanas del siglo XX: teoría de análisis
}

\author{
Alejandro Loeza \\ Universidad Marista \\ literalmente1984@hotmail.com \\ https://dx.doi.org.10.12795/futhark.2020.il 5.08
}

Fecha de recepción: 23.02 .2020

Fecha de aceptación: 12.05 .2020

Resumen: El artículo plantea una interpretación estética de las narrativas latinoamericanas del siglo $\mathrm{XX}$ para analizar las dictaduras desde la literatura. El planteamiento de análisis de la estética literaria revela la profundidad que la narrativa latinoamericana adquirió ante las dinámicas contra la libertad por parte de los procesos históricos y políticos de la región. El planteamiento teórico recurre a obras emblemáticas de la llamada novela de dictador para ejemplificar la estética del compromiso, para dar paso al análisis de obras que no mencionan directamente a dictadores y tiranías, pero que su estética se corresponde con la represión política y la anulación de las libertades civiles.

Palabras clave: literatura latinoamericana, dictaduras, autoridad, poder, estética literaria.

\section{Literary aesthetics of the Latin American dictatorships of the $20^{\text {th }}$ century: analysis theory}

\begin{abstract}
The article proposes an aesthetic interpretation of Latin American narratives of the 20th century to analyze dictatorships from literature. The analysis approach of literary aesthetics reveals the depth that the Latin American narrative acquired in the face of the dynamics against freedom on the part of the historical and political processes of the region. The theoretical approach uses emblematic works of the so-called dictator novel to exemplify the aesthetics of compromise, to make way for the analysis of works that do not directly mention dictators and tyrannies, but that their aesthetics corresponds to political repression and the annulment of civil liberties.
\end{abstract}


Keywords: Latin American literature, dictatorships, authority, power, literary aesthetics.

Sumario: I. Aproximación a una estética de las dictaduras. 2. La estética de la dictadura: aproximación a tres posturas. 3. Hacia una teoría estética de la dictadura literaria.

\section{Aproximación a una estética de las dictaduras}

La relación entre la literatura y el compromiso es amplia e incluye temas como la conciencia, la implicación social y el compromiso con el contexto. El artículo que presento se delimitará a analizar narrativas latinoamericanas del siglo $\mathrm{XX}$ que fueron escritas bajo las dictaduras, desde el exilio o como procesos históricos.

El concepto de compromiso y responsabilidad, en el marco del discurso literario, implica explorar la implicación de la literatura en la conciencia cultural, política y social del creador y el receptor. Sin embargo, el artículo no versa sobre las dimensiones políticas o éticas de la literatura con relación a las dictaduras, sino en la estética representada en la literatura latinoamericana del siglo $X X$, como una manifestación del compromiso. Si bien podemos definir el compromiso del autorescritor como el pacto que establece entre su contexto y la denuncia social, en las dictaduras y denuncia de ellas, el autor adquiere un sentido más amplio de conciencia y compromiso: el de la responsabilidad. Los textos narrativos que abordo en este artículo son la manifestación explícito de un compromiso estético con la denuncia, pero quiero establecer que la estética del compromisos es inherente a obras que han sido catalogadas como evasiones de los temas políticos y sociales.

El escritor, como creador de arte, tiene un papel social, lo cual implica un compromiso social manifestado en la expresión. Sin embargo, podemos observar que en todas las manifestaciones literarias existen diversos noveles de responsabilidad con el contexto social. Esa responsabilidad es lo que genera una estética específica, una estética del compromiso en lo relativo a temas de dictadura. La relación entre dictaduras y literatura es un reclamo que se ha hecho desde los propios escritores e intelectuales de todas las épocas:

¿Por qué no van a intervenir (los intelectuales en la política)? ¿es que los intelectuales no son ciudadanos como los demás? ¿Acaso no pagan contribuciones? ¿No entran en quintas? ¿No van a Marruecos? ¡Pues entonces! ... esos jóvenes que se llaman de vanguardia y que quiere dirigir Ortega y Gasset, no tienen ni idea, los pobrecitos... Creen que para escribir hay que ir a buscar a Francia la última moda, y que una etiqueta, un programa, una escuela, 
un nombre, son atributos suficientes para llamarse original y de vanguardia (Valle-Inclán 1994: 28I).

Esta postura del escritor español se convirtió en una estética en la literatura de su país con las dictaduras del siglo $X X$ en la península ibérica. Décadas después, en $Y_{0}$ el supremo de Augusto Roa Bastos recrea la historia de un dictador como metáfora del momento que el autor vive en Paraguay. Así, el autor explica la relación cultural y la necesidad estética que las dictaduras crearon en el continente latinoamericano:

Hablar de la funesta influencia del poder cultural no es olvidar el poder político
represivo, agente y responsable principal de todos estos males, instalado
despóticamente en la mayor parte de nuestros países. Pero en la medida en
que la existencia y la acción del poder cultural supone -desde luego
falazmente- el apoyo organizado y masivo a favor de la cultura por parte del
formidable aparato del capital financiero internacional, la existencia y la acción
del poder político represivo implica de hecho la imposibilidad de toda acción y
expresión cultural más o menos constructiva y coherente. (Roa 1991: 87).

Otros autores como Gabriel García Marquez, simbolizaron las dictaduras bajo la metáfora de un patriarca, modelo de todos los dictadores latinoamericanos. Y si bien, no todos los autores retrataron directamente al dictador en sus obras, otros escribieron su obra como una denuncia circunstancial al poder, como José Revueltas, quien desde la denuncia militante, escrita en prisión durante la represión de los eventos de México en 1968, retrata las concecuencias de la represión, muy similares a los de una dictadura democrátizada. El objetivo de este análisis no es determinar la estética de las llamadas novelas de dictadura, acotadas, estudiadas y analizadas en varias obras, sino una estética de dictadura no declarada por el autor/narrador de manera abierta. Lo anterior se ampara en la imposibilidad explícita de algunos autores de construir una ficción en medio de un contexto de censura y represión, como es el caso de la obra de Revueltas o Borges. Así, suscribo lo dicho por Bajtín: la necedidad del artista-creador de asumir una responsabilidad dentro de su obra, aunque sea a través de la evasión:

\begin{abstract}
Yo debo responder con mi vida por aquello que he vivido y comprendido en el arte, para que todo lo vivido y comprendido no permanezca sin acción en la vida. Pero la responsabilidad se relaciona con la culpa. La vida y el arte no sólo deben cargar con una responsabilidad recíproca, sino también con la culpa. Un poeta debe recordar que su poesía es la culpable de la trivialidad de la vida, y el hombre en la vida ha de saber que la falta de exigencia y de seriedad en sus problemas existenciales es culpa de la esterilidad del arte. (Bajtín 20I2: 27)
\end{abstract}

El compromiso en las obras que citaré, son ejemplos conocidos de estética reaccionaria ante situaciones excepcionales, donde las situaciones límite y la "necesidad" del autor por escribir, burlando la censura o sin mencionar un régimen específico, crearon dimensiones estéticas que ahondan en el clima de las dictaduras 
y la represión. Es la estética en forma de compromiso lo que hace a la narrativa latinoamericana lo que delimita las dictaduras y tiranías. El tema es vasto y complejo: por ello, me restrinjo a literatura hispanoamericana del siglo $X X$.

Las novelas que exploran las estructuras del poder, el funcionamiento y conductas de los poderosos, las dictaduras, el modelo de tirano o la situación de los gobiernos latinoamericanos, abundan en el siglo $\mathrm{XX}$, momento de crisis múltiple (política entre otras) en el que particularmente la figura del dictador está en el punto de mira de escritores e intelectuales, además de concentrar numerosas reacciones culturales. Esta literatura entorno al dictador ha hecho "el inmenso favor de ponernos en guardia contra el olvido" (García Márquez en Ramírez Amaya 1976: 12).

Obras como Yo, el supremo de Augusto Roa Bastos, El otoño del patriarca de García Márquez y La fiesta del chivo de Mario Vargas Llosa, constituye un caso especialmente significativo, por su condición de novelistas de éxito editorial con nombramientos políticos y/o reconocimientos internacionales. A diferencia de la narrativa previa al boom latinoamericano, la fórmula que utilizan estos autores, es una reflexión histórica de la misión pedagógica de los novelistas, auxiliar en el desenmascaramiento de los procesos históricos del siglo XIX y XX. En este sentido:

El dictador no se origina como personaje específico de la literatura latinoamericana, pero al haberse consolidado como un lugar común de la realidad política de cualquier régimen transoceánico, se ha constituido en foco de atención permanente para los escritores de esta zona del mundo (Noguerol 1992: 92)

Es el mismo Noguerol quien en su excelente artículo de 1992 hizo un catálogo-taxología de los dictadores latinoamericanos en la literatura. Además, recoge y considera la teoría de Calviño Iglesias que ahonda en una teoría estética, catalogando a los personajes de las novelas de dictadura en mesiánicos, patrioteristas, salvacionistas, megalomaniacos, tanatofílicos y misantrópicos. El estudio al que remito es muy completo, pero considera al personaje declarado como dictador dentro de la narrativa, excluyendo la posibilidad de que el tirano y transgresor de la libertad no aparezca en la obra. Rememórese la obra de José Revueltas, El apando, donde el clima de represión política e ideológica están presentes en un espacio de confinamiento, no sin el ambiente que evoca una estética del compromiso.

Para lograr una interpretación de la estética del compromiso literario hacia la denuncia de sistemas dictatoriales, es importante aclarar que el término es sinónimo de crítica hacia las tendencias políticas e ideológicas que cesan cuatro aspectos de la vida político-social de un grupo humano: a) la representación política 
de la alteridad; b) el cese o anulación de los derechos humanos; c) la libertad de expresión en cualquier faceta y d) represión policiaca-militar de la sociedad civil. Estas cuatro características pueden ser encontradas con facilidad en las novelas del dictador, pero iqué ocurre con la obra de escritores mexicanos como José Revueltas, Juan Rulfo, Carlos Fuentes, Nicolás Guillén, Virgilio Piñeira, Jorge Luis Borges, etc.? El contexto político de los escritores antes mencionados no es el de abierta denuncia a los gobiernos en los que escribieron. $Y$, sin embargo, encontramos al menos una de las cuatro distinciones que previamente he realizado sobre lo que implica una estética de dictadura.

De ahí reafirmo que el compromiso de los autores con la denuncia de las dictaduras, no es de carácter militante (cómo si lo puede ser en Roa Bastos, Vargas Llosa y García Márquez). En cambio, afirmo que, en todos los casos citados, la doctrina general es el ars gubernandi, pues se trata de un análisis de la imagen del poder, donde la obra literaria tiene un sentido crítico que ataca el sistema político latinoamericano, a través de la estética del compromiso, en ocasiones, sin militancias políticas. En este sentido, las obras literarias escritas bajo dictadura postulan dos elementos de lo que he llamado estética del compromiso bajo dictaduras:

I) postula un universo representado que se erige en signo (evidente o simbólico, ocultatorio o esclarecedor, aquiescente o polémico) de esa realidad; y 2) entraña los elementos que pueden remitirnos a los reales factores histórico-sociales que intervienen en su producción y recepción, y que pueden determinar su índole formal y significativa. (Bueno 1986: 27)

Ejemplo de lo anterior son las posturas que han acusado a Vargas Llosa o García Márquez como partícipes de movimientos políticos de derecha o izquierda. Si bien, el caso del peruano tiene sentido por su militancia política en la vida política de su país, sus obras tienen un sentido pedagógico. Considero indispensable hacer valer la separación entre autor y obra para destacar la estética (no libre de contexto) del compromiso. La materia en común a todas las obras que he mencionado es la dictadura que ejerce tiranías, ya sea desde la filosofía política de la izquierda o derecha, que se manifiestan en una estética de compromiso con la denuncia del cese de las cuatro actividades previamente explicadas.

Las imágenes del poder que los autores proyectan a través de su obra se manifiestan ya en la exaltación de las manías de los tiranos, ficticios o reales. Esta imagen directa del dictador-tirano se halla en las descripciones de varios autores latinoamericanos, bajo el símbolo del nivel de compromiso que asumieron con respecto a la verdad literaria, como denuncia y horrorizarían ante la psiquis del tirano-dictador. 


\section{La estética de la dictadura: aproximación a tres posturas}

Considero tres actitudes que los novelistas latinoamericanos adoptaron ante las dictaduras y tiranías a manera de reacción ante una situación política que supuso la negación de libertades básicas y donde la oposición política era merecedora de penas de cárcel o exilio. Dichas estéticas se corresponden con lo sugerido por Galeano, quien escribe sobre la dictadura argentina: "Los argentinos -dicen- nos dividimos en: aterrados, encerrados, enterrados y desterrados" (Galeano 2010: 14). Las tres estéticas que analizo en este artículo y que propongo para futuros estudios de narrativas en el siglo $X X$ son: vivencial, histórico y militante. Las tres tienen carácter de compromiso y las utilizaré para analizar las obras mencionadas, a fin de exponer una estética intrínseca a cada obra, que puede servir en el análisis de otras literaturas de dictadura durante el siglo $X X$.

Estas tres actitudes narrativas, por lo que ya he definido como compromiso, la estética vivencial (víctima), histórico (observador-testigo) y militante (denuncia), son posturas narrativas que introduce a) el narrador y/o b) el personaje principal. En la narrativa latinoamericana el hecho histórico es importante para el análisis, y en este apartado lo considero intrínseco a la dinámica narrativa, pues las disposiciónes de una estética que expone a las dictaduras establece un poder absoluto tiránico que se opone a un poder civil. Las reacciones estéticas de los personajes/narradores exponen la dictadura-tiranía, por lo que se expone una respuesta "obligada" por parte de los personajes/narradores ante una situación que violenta la vida pública, civil y de libertad. Naturalmente, esto se relaciona con el poder en términos de Foucault:

Lo importante, creo, es que la verdad no está fuera del poder ni sin poder (no es a partir de un mito del que habría que recoger la historia y funciones, la recompensa de los espíritus libres, el hijo de largas soledades, el privilegio de los que han sabido librarse). La verdad es de este mundo; se produce en él gracias a múltiples coacciones. Y detenta en él, efectos regulados de poder (Foucault 1986: 143).

No se puede entender la reacción de los escritores latinoamericanos a los gobiernos dictatoriales sin conocer la historia política, en la complejidad de los procesos de la conquista, colonia e incipidas independencias del siglo XIX. Sin embargo, el fracaso de los primeros gobiernos latinoamericanos, bien por la degradación de la autoridad y el poder y las luchas por el mismo al interior de los países, llevó a muchos de estas jóvenes naciones a la radicalización, inestabilizando las democracias y repúblicas y cayendo en el encanto de las primeras dictaduras.

Así, autores con Alejo Carpentier exploraron el fracaso de esos gobiernos en El reino de este mundo (1949) donde el cubano rememora la revolución haitiana, 
donde el personaje principal, Ti Noel, vive los excesos de los franceses, primero, y del rey Henri Christophe después. En ese análisis retorspectivo participan otros escritores del siglo XX, como el paraguayo Augusto Roa Bastos con la novela Yo el supremo de 1974, la cual es una excelente perspectiva histórica del dictador Rodríguez de Francia, con datos que se apegan a la realidad histórica, sin dejar de remitir a los excesos, exentricidades y a la anulación de la libertad de la joven nación paraguaya, donde:

\begin{abstract}
El doctor Francia es abordado por la novela en su función de gobernante, cuando tiene tras de sí la casi totalidad de su dictadura y cuando el ser humano que es, ha devenido íntegramente el poder. La conocida austeridad de su vida, la dedicación exclusiva a su tarea, la falta de lazos amistosos o sentimentales, la implacable soledad en que vivió hasta el fin, disuelven otros aspectos de su existencia -salvo, en el presente, el corporal y espiritual trance de la enfermedad y la muerte; salvo, en el pasado, bajo las formas de la evocación, el recuerdo de la juventud y años adultos- trasuntándolo en el ejercitante del poder, en el celoso guardián de la nacionalidad y en el ansioso capitán de su desarrollo. (Rama 1982: 33).
\end{abstract}

Otra novela de dictador con la caractéristica estética histórica es La fiesta del chivo de Mario Vargas Llosa, pero con una dictadura acaecida en República Dominicana a principios del siglo $X X$, donde el brutal dictador Rafael Trujillo es retratado por el novelista en sus dimensiones más excéntricas, brutales y salvajes.

Las obras antes citadas son ejemplo de una estética histórica-militante: los personajes/narradores relatan los excesos pasados, los golpes de Estado y recrean las atmósferas de benevolencia y represión de los tiranos. En la estética militante, las obras analizan la esencia de las dictaduras, ya que la perspectiva histórica permite analizar la constitución ideal-utópica de las repúblicas hasta sus fracasos tiránicos. Ninguno de los que escriben bajo la estética histórico-militante ha vivido los excesos de las dictaduras que han recreado y utilizan la licencia poética que les permite analizar los temas políticos desde la oposición de sus personajes al régimen de los personajes principales.

Incluso Jorge Luis Borges quien no escribió directamente sobre las dictaduras de su época o anteriores, si pronunció en un par de ocasiones una análisis sobre ellas. Para Borges, las dictaduras están relacionadas con la monotonía, algo que en su obra (El Aleph, por ejemplo) es recurrente:

Las dictaduras fomentan la opresión, las dictaduras fomentan el servilismo, las dictaduras fomentan la crueldad; más abominable es el hecho de que fomenten la idiotez. Botones que balbucean imperativos, efigies de caudillos, vivas y mueras prefijados, muros exornados de nombres, ceremonias unánimes, la mera disciplina usurpando el lugar de la lucidez. Combatir esas 
tristes monotonías es uno de los muchos deberes del escritor. (Borges 1988:

46)

Esta evolución hacia la oposición de los regímenes dictatoriales latinoamericanos es una transición paralela en la medida en la que los gobiernos se hicieron tiranías. Queda para otra investigación la literatura que fue favorable a las dictaduras latinoamericanas en el siglo XX. Y como Borges, muchos otros escritores no vieron la inherencia de exhibir a las dictaduras de manera directa, pero si desde la estética literaria: los ambientes, las incertidumbres, el espacio y los tiempos. El autor argentino consideraba las dictaduras como una salida política pero iluso e ingenua: "Las dictaduras podrían ser buenas, pero en general no lo son. Porque la dictadura ilustrada es una utopía y las dictaduras militares son las peores" (Borges 1988: 49).

Pocos escritores quedaron al final de las dictaduras del lado del dictador. Para el caso, este artículo no verifica la efectividad crítica de la literatura latinoamericana en contra de las dictaduras, sino la disposición estética de sus autores. No se puede simplificar la literatura de dictadura a una abierta denuncia ya que "Son muchas las vertientes que utilizan los escritores contemporáneos; sus perspectivas son optimistas o pesimistas, ya que niegan o afirman sus herencias, pero en todo caso la historia es considerada como una carga que debe ser revelada, dominada, negada" (Souza 1986: 27).

Los escritores latinoamericanos que habían logrado consolidarse después del boom latinoamericano, establecieron una postura estética ante la dictadura: ni uno quedó indiferente. En ese sentido, la proyección del escritor dentro de sus obras es un símbolo de inconformidad, lo cual es parte del hecho literario, material con el que teorizo. Obras como las de García Márquez, Carlos Fuentes, Vargas Llosa, Miguel Ángel Asturias, Ricardo Piglia y Roa Bastos le dan una identidad estética de carácter político a la literatura latinoamericana del siglo XX. Los elementos estéticos de la dictadura desde la perspectiva de estos autores ( $y$ otros que iré mencionando) no es exclusiva ni excluyente de otras manifestaciones. $\mathrm{Si}$ bien establezco una estética literaria, esta es una aproximación y/o primer esbozo de un trabajo más complejo y completo que deberá considerar textos de prensa, diarios, epistolarios y lo anterior compulsado con las obras literarias publicadas en fechas específicas. Así se podrá llegar al hecho literario. Aquí solo exploro el alcance estético de futuros análisis.

Dicho lo anterior, retomo. La estética que encuentro en las obras latinoamericanas escritas durante el siglo $X X$ son: vivencial, histórica y militante. Esta estética se establece a través de un compromiso con respecto a una dictadura, referida (vivencial), recuperada (histórica) o de denuncia (militante). A cada estética propuesta (y no excluyente una de la otra) se deberá cotejar con la generación, 
movimiento y/o corriente literaria a la que se adscribe. Lo anterior es fundamental, pues configura el posicionamiento estético de los escritores latinoamericanos, para luego actuar en consecuencia literaria. No se puede realizar este análisis sin considerar a las corrientes, movimientos y/o manifiestos literarios, ya que en ocasiones sirvieron como trinchera en contra del poder, ya que amparados por un grupo, los escritores eran capaces de crear discursos, en apariencia, inofensivos para el dictador.

De las tres estéticas propuestas, la más recurrida es la vivencial: esto porque autores como García Márquez, Borges, Cortázar, Vargas Llosa, Isabel Allende, Ricardo Piglia y Roa Bastos, vivieron bajo alguna dictadura, de inspiración soviética o fascista, alimentada, en todos los casos, por fuerzas e intereses exteriores. Las dictaduras latinoamericanas del siglo $X X$, obligaron a los escritores más conocidos y los que comenzaron sus carreras, a posicionarse ante las situaciones políticas de su país y del extranjero. En Yo, el supremo, la no linealidad demencial del tirano es una clave estética de la ambigüedad histórica:

Yo no escribo la historia. La hago. Puedo rehacerla según mi voluntad, ayudando, reforzando, enriqueciendo su sentido y verdad. En la historia escrita por publicanos y fariseos, éstos convierten sus embustes a interés compuesto. Las fechas para ellos son sagradas. Sobre todo cuando son erróneas. Para estos roedores, el error es precisamente roer lo cierto del documento. Se convierten en rivales de las polillas y los ratones. En cuanto a esta circularperpetua, el orden de las fechas no altera el producto de los fechos. (Roa 2017: 101).

Ahora, para enmarcar en un contexto homogéneo, la escritura bajo dictadura, lo que genera la estética vivencial, es aquella en la que el gobierno censura, persigue a la oposición política y desaparece y/o limita las expresiones artísticas. Bajo la estética vivencial, los escritores son oprimidos y a sus obras les caracterizará el desencanto por los ideales (políticos y filosóficos) siendo desfavorable su percepción de la sociedad. En estas obras, la deshumanización es parte de la denuncia, sin marcar un claro posicionamiento cívico, evitando la dinámica social y donde la monotonía de los espacios y el tiempo narrativo, anulando el hecho histórico: bajo las dictadura-tiranías representadas en una estética vivencial, no ocurre nada.

Como es de observarse, la propuesta teórica que propongo se fundamenta en la hermenéutica y el análisis literario, contextualizada por la historia de Latinoamerica. La estética de compromiso que analizo desde tres variantes (vivencial, histórico y militante) puede aplicarse bajo la premisa de una pregunta hermenéutica: ante la dictadura-tiranía ¿qué respuesta daban a esas circunstancias, a las consecuencias y la postura que se asume desde el poder? Los conceptos teóricos que aquí propongo son herramientas interpretativas. Bajo la estética 
vivencial, histórica y/o militante, se analiza la postura de la obra, no la actuación civil del autor. Más aun, la estética de las dictaduras es una alternancia de la realidad, no una referencialidad: "Escribir no significa convertir lo real en palabras sino hacer que la palabra sea real. Lo irreal sólo está en el mal uso de la palabra, en el mal uso de la escritura" (Roa 2017: 62).

Así, los escritores vivenciales son aquellos que dejan de lado las circunstancias políticas porque no consideran que sea materia de una obra de arte como la que llevan a cabo. El mejor ejemplo de estética vivencial es la obra de Jorge Luis Borges y Octavio Paz. Ambos escritores viven bajo dictaduras o peligro de represión política y cada uno decide no retratar de manera explícita la política de sus respectivos países. Bajo lo vivencial se puede encontrar una literatura que no denuncia directamente el régimen. Lo anterior ocurre por los parámetros de "verdad" en el contexto del escritor:

Cada sociedad tiene su régimen de verdad, su 'política' general de la verdad, es decir, los tipos de discurso que acoge y hace funcionar como verdaderos o falsos, el modo como se sancionan unos y otros; las técnicas y los procedimientos que están valorizados para la obtención de la verdad; el estatuto de quienes están a cargo de decir lo que funciona como verdadero. (Foucault 1986: 143).

Por su parte, la estética militante es aquella en la que la obra se hace para revelar la identidad política de los personajes en pro de una ideal político. Generalmente, establecen una abierta oposición a las dinámicas de represión política y a favor de la revolución o un ideal contrario al gobierno. En este sentido, la obra de José Revueltas puede ser un ejemplo de la denuncia de un gobierno que no es una dictadura acusada, sino una democracia simulada donde la represión y los espacios, narradores y personajes, son víctimas del Estado. La obra Respiración artificial de Ricardo Piglia también clasifica como estética militante, pues la narrativa nos lleva a los límites de conocer y explorar la historia borrada y callada por las dictaduras.

La estética de compromiso histórico son aquellas que denuncian a través de la metáfora histórica, los excesos de las dictaduras-tiranías, asumiendo los personajes la responsabilidad social de destruir dichas dictaduras o bien, criticando la dictadura desde la perspectiva del tirano. Estas obras son las más numerosas en mi recuento de las narrativas latinoamericanas, pues ahí encontramos los pilares de la llamada novela del dictador, como Yo, el supremo de Augusto Roa Bastos, El otoño del Patriarca de Gabriel García Marques y La fiesta del chivo de Mario Vargas Llosa. La estética histórica no obliga a la fidelidad histórica, sino a la referencialidad: "La novela que utiliza el acontecimiento histórico como tema, y que parte de una previa investigación de los hechos que han de novelizarse, independientemente de que éste, a la larga, resulte más o menos 'trabajado' por la imaginación -y aún por la 
fantasía- del narrador" (Márquez 1985: 164). Este compromiso estético histórico, tiene su metáfora en el contexto del autor, pues:

La historia y la narrativa son frecuentemente consideradas entidades separadas, estando la Historia basada en datos e información, y la narrativa en la imaginación creadora (...) White afirma que los historiadores utilizan estrategias estéticas al construir sus interpretaciones del pasado, y considera que la historia y la narrativa sólo están separadas en teoría. Por lo que concierne a la novela histórica, es evidente que una no puede existir sin la otra. (Souza 1988: 27).

Así, la clasificación de la estética de las dictaduras desde tres posturas, se basa en la el análisis literario y no en el ideológico, centrándose en la literariedad. Lo anterior permite analizar la estética de las dictaduras no solo en las obras que claramente critican y denuncian a las dictaduras y tiranías, sino también a aquellas que han sido acusadas de ser evasivas a los temas de dicha narrativa.

\section{Hacia una teoría estética de la dictadura literaria}

En este trabajo he intentado describir una estética de la dictadura literaria bajo circunstancias históricas y políticas determinadas. Los escritores latinoamericanos reaccionaron durante el siglo $X X$ a situaciones políticas adversas como las dictaduras militares, civiles y disfrazadas de democracia $\circ$ alternancia de poder, es decir, la negación de libertades y donde la oposición política era reprimida. El hecho histórico es fundamental para comprender la estética de la dictadura literaria, donde se combinan las disposiciones del dictador y la respuesta social. Roa Bastos, fiel a una estética del compromiso vivencial e histórico, explica la relación entre realidad, literatura y dictadura:

Del Poder Absoluto no pueden hacerse historias. Si se pudiera, El Supremo estaría demás: En la literatura o en la realidad. ¿Quién escribirá esos libros? Gente ignorante como tú. Escribas de profesión. Embusteros fariseos. Imbéciles compiladores de escritos no menos imbéciles. La palabra de mando, de autoridad, palabras por encima de las palabras, serán transformadas en palabras de astucia, de mentira. Palabras por debajo de las palabras. Si a toda costa se quiere hablar de alguien, no sólo tiene uno que ponerse en su lugar: Tiene que ser alguien. Únicamente el semejante puede escribir sobre el semejante (Roa 2017: 30).

Esta es la línea de la literatura latinoamericana que estudio y me interesa analizar de manera específica, con la idea de una estética de la dictadura literaria que sea verificable en su hermenéutica. Las dictaduras afectaron a la escritura y los escritores se obligaron a responder de manera estética, desde una perspectiva u otra: vivencial, histórica o militante. La vivencial es, como he explicado, aquella que retrata la vida bajo la dictadura, sin asumir una voz crítica ni de abierta denuncia. El 
histórico utiliza la mediación de los antiguos dictadores para crear una metáfora de la realidad nacional y/o continental. Y, finalmente, la estética militante es la que denuncia una dictadura específica, generalmente, desde el exilio del autor.

El breve repaso a esta propuesta estética que hago a la estética de las dictaduras literarias se relaciona con el área cultural y educativa de los autores latinoamericanos, no siendo excluyente de otras manifestaciones hispanohablantes (como, por ejemplo, la literatura española del siglo XX). Mi propuesta de análisis teórico desde la estética implica conocer la historia política de la obra, sin importar la tendencia política o ideológica. Lo anterior explica procesos estéticos en los autores latinoamericanos ya que, todo golpe de Estado, creaba una expectativa social y por parte de los intelectuales. En un principio, no era fácil posicionar la obra con respecto a la expectativa tremendista del dictador.

La literatura con estética vivencial, generó, en un primer momento y en algunos casos, una disposición o neutralidad a las dictaduras. Con el pasar de los años, los escritores e intelectuales se alejaron de la figura de los dictadores, pues comenzaron a simbolizar lo anti-intelectual. Aun así, como afirma Juan Mayorga:

\begin{abstract}
El artista suele tenerse por el hombre más libre. En realidad, puede ser más vulnerable que el hombre común a la caricia y al puño del poderoso. Sobre todo cuando de éste dependen la realización o la difusión de su arte. $O$ cuando se hace la ilusión de que su obra, cambiando el alma del poderoso, puede cambiar el mundo. Recíprocamente, el poderoso, que a menudo ignora al hombre de cultura, busca a veces su compañía. Como si la mera cercanía del intelectual proporcionase al hombre práctico -ante la opinión pública o ante sí mismo- una cobertura estética $\circ$ incluso una legitimación moral. (Mayorga 1999: 4I).
\end{abstract}

Las disposiciones estéticas de la literatura a las dictaduras no implicaron, en ningún caso, un punto de inflexión para el derrocamiento o fin de dichos regímenes. Los fracasos de los dictadores en América Latina y la fama de la represión política no aminoraron la crítica o, como mínimo, escepticismo desde a) las universidades, b) los grupos intelectuales y c) los escritores que previo a la dictadura habían logrado notoriedad editorial. Salvo casos emblemáticos, ni los intelectuales ni la comunidad académica fueron una oposición real a las dictaduras, pues el alcance de la represión era una amenaza constante, con emblemáticas represiones en la década del sesenta y setenta. En realidad, los escritores latinoamericanos no fueron percibidos por las dictaduras como un peligro a la hegemonía autoritaria y en el caso de que sí, fueron exiliados o encarcelados.

Lo que revela un análisis estético del compromiso literario latinoamericano no es la injerencia que tuvieron esas obras en la política del dictador, sino el simbolismo social, humano y de denuncia que quedaron plasmados. Esta literatura 
habla de la relación entre el escritor y la vida social, desde el aspecto civil como cultural.

Así, el presente artículo es una introducción a la estética de las dictaduras literarias vía tres posturas (vivencial, histórica, militante) en la que el objeto es analizar la literariedad de la intervención de los escritores en condiciones políticas de dictadura. Con este primer acercamiento teórico, se concluye que las expresiones literarias de las dictaduras no son referencias directas a la misma. En lo sucesivo seguiré tratando el tema con ejemplos específicos de cada estética, desde las obras específicas y desde la generación literaria a la que cada escritor se adscribió. Sin embargo, este marco de análisis es atractivo para estudiar obras escritas y publicadas en contextos de represión que no eran, necesariamente, dictaduras militares o civiles.

El boom latinoamericano es un referente histórico donde confluyen estéticas fundamentales y diferentes para la literatura del siglo XX. La importancia e influencia de esta corriente literaria, a veces abyecta y renegada por sus miembros, radica en que no hubo una postura manifiesta en contra de las dictaduras, pues los escritores sirvieron antes a sus coordinadas estéticas, actuando en consecuencia al acto literario, antes que al político. Que sus novelas, poemas y cuentos hayan recogido las dictaduras, desde la perspectiva vivencial, histórica o militantes, es, en realidad, secundario. Es decir, la literatura latinoamericana del siglo $X X$ se emancipa del rigor de panfleto ideológico o de reivindicación política, en pro de la estética para defender, sin exagerar, la militancia literaria, con una narrativa que es más autónoma y latinoamericana. Naturalmente, todo lo dicho es una pretendida teoría general del relato literario latinoamericano del siglo $X X$, que busca encajar en el análisis de una estética de compromiso, la cual sólo se manifiesta bajo una dictadura. Los ejemplos específicos y las discrepancias de lo que aquí afirmo, serán tarea de otros artículos propios y ajenos.

En este sentido es importante aclarar que el boom latinoamericano no mantiene una hegemonía estética y que la mención que he hecho en este artículo a dicha generación/movimiento, acota una temporalidad (el siglo $X X$ ) y un espacio lingüístico (Hispanoamérica). En la producción de las distintas corrientes literarias del siglo $X X$, influyó el valor o desinterés político, según el momento y circunstancia de los autores. Así, en la clasificación de autores que propongo en este artículo, vivencial, histórica y militantes, es importante observar que la más nutrida es la histórica y militantes. La filología está en deuda con la búsqueda de la literatura escrita desde las represiones del poder y la autoridad latinoamericanas, la cual supuso la complejidad de que los textos fueron censurados y/o destruidos. A todas estas estéticas de las dictaduras y la represión les caracteriza ser reacciones meditadas a las circunstancias políticas: se escribía para burlar la represión y censura, en pro del arte. Ante la emancipación estética de la literatura 
latinoamericana del siglo $X X$ con respecto a la europea ( $y$ sobre todo española), esta creó sus parámetros estéticos, profundamente marcados por las dictaduras y tiranías. En realidad, las estéticas vivenciales, históricas y militantes se nutren de tres características: la estética colonialista, la de tipo fascista y la soviética. En los tres casos la literatura respondió a eventos sociales y políticos que les eran contemporáneos o bien parte del pasado.

La estética del compromiso histórica utilizó la estética colonialista (El reino de este mundo de Carpentier o Yo, el supremo de Roa Basto, por ejemplo), mientras que las vivenciales utilizaron la estética fascista (Respiración artificial de Piglia) como denuncia, y la militante utilizó la estética comunista-soviética (Dormir en tierra de Revueltas). Es importante observar que ninguna obra que haya trascendido sobre el posicionamiento radical de algunos de los escritores. No existió una presión para denunciar las dictaduras por parte de la literatura, ya que no en todas las situaciones se dio una censura total o parcial a la cultura.

En general, el control de las dictaduras latinoamericanas se dio en el ámbito periodístico y en la propaganda oficial, que no incluía manifestaciones culturales, las cuales eran producidas bajo la vigilancia del régimen. Los escritores, en este contexto opresivo, no fueron obligados (en todos los casos) a escribir propaganda del gobierno, sino a no interferir con el régimen.

Por lo tanto, este artículo es una aproximación teórica a las numerosas manifestaciones literarias hispanoamericanas del siglo $X X$, que a través de determinadas estéticas crearon espacios de reflexión sobre la sociedad, política y cultura latinoamericana. Considerando todo lo anterior, la historia de las reacción literarias a las dictaduras hispanoamericanas se distinguen por dos rasgos principales. En primer lugar, pocos libros se han ocupado de esta relación entre dictaduras y la estética literaria que produjo y, en segundo lugar, los escritores que publicaron bajo las dictaduras, son mayoría, pero no abiertamente denunciantes. Lo importante de la teoría estética que propongo como análisis es la posibilidad de indagar la represión, el compromiso y la atmosfera destructora de las dictaduras latinoamericanas a través de textos que no son abiertamente ni un denuncia, ni una acusada postura en contra de los regímenes.

La literatura de estética vivencial, histórica o militante de las dictaduras reduce el hecho histórico a literariedad. Las acciones narrativas proponen la clasificación estética, que servirá para iniciar un debate para mejorar el estudio de la literatura escrita bajo dictaduras latinoamericanas. No ha sido el objeto de estudio del presente artículo definir las variantes y posibilidades de la teoría literaria, que ocupan varios volúmenes de extensión y que el lector especializado en crítica no tardará en ubicar en los estudios de literatura. En cambio, este artículo es una propuesta teórica autónoma, de carácter hermenéutico, que 
explora las principales obras de la conocida novela de dictador en el contexto hispanoamericano.

El artículo ha analizado las constantes de las obras más emblemáticas de Vargas Llosa, Roa Bastos, García Márquez y Carpentier, para ser ejemplo del potencial circunstancial que existe para analizar obras que no hacen una abierta denuncia a las dictaduras, como la obra de Borges, Rulfo o Cortázar. Los conceptos teóricos que he manejado y que he formulado busca respuestas en la literatura vivencial, aquella que se escribió en el silencio, sin una denuncia frontal, de ahí lo aventurado, riesgoso y teórico del presente artículo.

Así, estéticas vivenciales, históricos y militantes, según la obra, pueden ser analizados desde las circunstancias de la obra de arte, mientras que los militantes son aquellos que subvierten la autonomía de la obra al servicio del idealismo libertario. Los escritores históricos son aquellos que crearon metáforas de las circunstancias sociales y políticas del siglo $X X$, asumiendo la responsabilidad social de escribir para rememorar y adoctrinar en contra de las dictaduras. Esta forma de clasificar a los escritores, desde los criterios estéticos, es importante para elaborar una historia literaria y no ideológica. $Y$ como he afirmado, la importancia de ensanchar la crítica hermenéutica en torno a las dictaduras y sus narrativas, es rescatar el compromiso de los escritores quienes, consciente o inconscientemente, denunciaron los excesos de todo orden que destruía la libertad, social, política y creativa.

\section{Referencias bibliográficas}

BAJTín, M. (2012). Estética de la creación verbal. México: Siglo Veintiuno Editores.

BORGES, J. L. (1988). Borges A/Z. Argentina: Biblioteca de Babel.

BUENO, R. (1986). Teoría literaria y desarrollo social en América Latina. Revista Hispánica. 43, año XV, 27-42.

CARPENTIER, A. (2017). El reino de este mundo. España: Nueva Alianza.

FOUCAULT, M. (1986). Un diálogo sobre el poder. Madrid: Alianza.

García Márquez, G. (2000). El otoño del patriarca. México: Editorial Diana.

GALEANO, E. (2010). Días y noches de amor y guerra. México: Siglo XXI Editores.

MÁRQUEZ, A. (1985). La tragedia del Generalísimo: realidad y proyección de un nuevo mundo. Revista Casa de las Américas, I48, año XXV, I6I-I77.

MAYORGA, J. (1999). Cartas de amor a Stalin. Las puertas del drama, 0, 38-5I.

NOGUEROL, F. (1992). El dictador latinoamericano. Aproximación a un arquetipo narrativo. Philologia Hispalensis, VII, 9I-I02.

PIGLIA, R. (2005). Respiración artificial. La Habana: Casa de las Américas.

RAMA, A. (1982). La novela latinoamericana: 1920-1980. Bogotá: Procultura.

RAMíreZ, A. (1976). Sobre la libertad, el dictador y sus perros fieles. Bogotá: Siglo XXI Editores. 
Revueltas, J. (1960). Dormir en tierra. México: Era.

ReVueltas, J. (1969). El apando. México: Era.

ROA, A. (2017). Yo, el supremo. Madrid: Real Academia Española de la Lengua.

ROA, A. (I99I). El texto cautivo (Apuntes de un narrador sobre la producción y la lectura de textos bajo el signo del poder cultural). Anthropos. Suplementos, $25,115-128$.

SoUZA, R. (1986). La historia en la novela hispanoamericana moderna. Bogotá: Tercer Mundo.

VARGAS, M. (20I5). La fiesta del chivo. México: Debolsillo.

VALLE-INCLÁN, J., y Javier Valle-Inclán (eds.) (1994). Entrevistas, conferencias, cartas. Valencia: Pre-Textos. 